develop them by using imported rhetoric, imported models, and large sums of money is to follow the failed policies of skyhooks. Attempting to build world-class universities without attending first to the educational and social ground on which such institutions might stand is, as Ivan Illich once said, "like trying to do urban renewal in New York City from the twelfth story up."

Rather than more world-class universities, what we really need in countries everywhere are more world-class technical institutes, world-class community colleges, world-class colleges of agriculture, world-class teachers colleges, and worldclass regional state universities. The United States doesn't have a world-class higher education system because it has many world-class universities-instead it has world-class universities because it has a world-class higher education system.

Ratings or rankings pretend to be objective and scientific; in reality, however, they are manifestations of ideologies about the purposes of higher education. In an era of globalization, world class has increasingly come to be synonymous with Western. That means science, research, and lots of money; poorer nations cannot afford to compete in this arena. The pressure to conform to "universalistic standards" is constant. Thus an institution that should be lauded for doing admirable work in its own domain may be considered a failure using world-class university standards. As nations strengthen and diversify their institutions, their excellence should not be judged by how well they emulate the West but rather by how successfully they exploit their rich traditions and cultures so that their institutions develop their own unique character.

\section{International Students in the United States: The Current}

\section{Picture}

\section{Rajika Bhandari and Hey-Kyung KoH}

Rajika Bhandari is director of research and evaluation and Hey-Kyung Koh is senior program officer, at the Institute of International Education. Address: IIE, 809 United Nations Plaza, New York NY 1003G, USA. Email: iieresearch@iie.org. More details on the Open Doors survey can be found at: http://opendoors.iietnetwork.org.

International student mobility is a rapidly growing phenomenon worldwide, with over 2.5 million students pursuing higher education outside their home country. Of this large number, over 500,000 students have studied in the United States in each of the past seven years. Although the United States has successfully maintained its status as the leading higher educa- tion destination for international students over the past half century, the numbers of these students and the leading countries of origin have varied in response to domestic and international political, economic, and academic factors.

The Institute of International Education (IIE) has collected data on international student enrollment in the United States

The number of international students enrolling in US higher education in the 2005/06 academic year stabilized at 564,766

since I9I9 and in the form of the Open Doors survey since I954/55. Approximately 3,000 regionally accredited US higher education institutions are surveyed annually on various aspects of international educational exchange. This article presents a summary of the key findings from the international student component of the Open Doors 2006: Report on International Educational Exchange.

After several years of minimal growth followed by modest declines (with steeper declines in certain fields and from certain world regions), the number of international students enrolling in US higher education in the 2005/06 academic year stabilized at 564,766-a nonsignificant decline of .05 percent from the previous year. While total international student enrollments remained steady, enrollment by new international students-students enrolling in US higher education for the first time-increased by 8 percent from the previous year.

\section{Where Do They Come From?}

While the United States hosts international students from all regions of the world, the majority of the international student population on US campuses (58 percent) came from Asia. In $2005 / 06$, four of the leading 5 and Io of the leading 20 places of origin were in Asia. Despite a 5 percent decline in numbers of students since the previous year, India remained the leading place of origin for the fifth consecutive year, accounting for 76,503 (I4 percent) of all international students. India was followed by China (II percent), Korea (Io percent), and Japan (7 percent). The only non-Asian country in the top five was Canada. The second-largest region of origin for international students was Europe, followed by Latin America, Africa, North America, and the Middle East. These regional distributions have remained relatively stable since 2002/03.

\section{Who Are They?}

In terms of academic level, the majority of international students in the United States are graduate students, as has been the case since 2001/02. In 2005/06, 47 percent were enrolled at the graduate level as compared with 42 percent at the undergraduate level, while is percent were enrolled in nondegree or certificate programs or pursuing postdegree "optional practical training." In addition, while international students overall 
comprise only a small proportion (4 percent) of total US enrollments, international graduate students accounted for 12 percent of the total US graduate student population.

A comparison of Open Doors data over the past 30 years indicates small but significant shifts in the demographic char-

\section{The majority of international students in the United}

States are graduate students, as has been the case since 2001/02.

acteristics of international students. In 2005/06, 44 percent of international students in the United States were female, a I3 percent increase from $1976 / 77$, when only a third were female. A larger proportion of international students ( 86 percent) were single in $2005 / 06$, as compared with 74 percent 30 years ago.

In addition to their academic and cultural contributions to US campuses, international students have a significant impact on the local, state, and national economy. In 2005/06, international students contributed almost \$13.5 billion to the US economy through expenditures on tuition, housing, books, fees, and other educational and living expenses. These expenditures are a direct outcome of the fact that nearly three-fourths of international students relied on personal and family funds as their primary source of funding for their higher education in the United States, while 26 percent relied primarily on funds from their US host university (mainly in the form of teaching or research assistantships, often from grants to the university from federal or other sources).

\section{Where Do They Study?}

While international students study throughout the United States and its territories, they tend to be concentrated in certain regions and states. For example, the metropolitan area of New York City hosted the largest number of international students (9 percent), followed by Los Angeles (6 percent), Boston (4 percent), Washington, DC (3 percent), and Chicago (3 percent). The top ro metropolitan areas hosted 36 percent of all international students studying in the United States in 2005/06, and the top 20 hosted nearly half ( 48 percent) of the total, further demonstrating that international students tend to be concentrated in a small number of urban areas. At the state level, California was the leading host, with 75,385 or I3 percent of international students, followed by New York (II percent), Texas ( 8 percent), Massachusetts $(5$ percent), and Florida (5 percent).

As in the case of geographic location, international students also tend to be concentrated in a small group of US institutions. Of the 564,766 international students in the United States in $2005 / 06$, over half (53 percent) were enrolled in just I43 institutions, each of which hosted I,000 or more international students. Not surprisingly, the top host states are also home to many of the top host institutions.
Myriad reasons explain the concentration of international students in certain US areas and institutions. These factors could include geographic and linguistic affinities to certain regions; gravitation toward areas or institutions where there are students or an immigrant population from their home country; preference for urban and large university towns; and the appeal of a certain institution because of the fields of study or degrees offered.

\section{What Do They Study?}

The popularity of business and management, and engineering among international students has remained relatively stable for the past five years. Business and management accounted for I8 percent of all international students in $2005 / 06$, while engineering accounted for a further $\mathrm{I} 6$ percent. At the other end of the spectrum, agriculture, education, and the humanities were selected by a small proportion of international students (ranging from $\mathrm{I}$ to 3 percent).

\section{Future Trends in International Student Enrollment}

Taken together, the two key findings of Open Doors 2006-the stabilizing of total international student enrollment and the increase in new, incoming students-suggest that total international student enrollment in the United States is likely to increase in the near future. These Open Doors findings, supported by similar trend data collected by the Council of Graduate Schools and other surveys, suggest that the United States has not lost its attraction as a destination of choice for international students. US institutions have stepped up recruitment of international students and adjusted their appli-

The popularity of business and management, and engineering among international students has remained relatively stable for the past five years.

cation procedures and admissions timetables to accommodate the lead time needed for visa approval. These university-level efforts have been complemented by the US Department of State's proactive steps to streamline the visa application and approval process, and to promote the United States as a welcoming place for international students. The results of these efforts by government and academia appear to be turning the tide, as reflected in the most recent Open Doors findings.

The Open Doors project has received support since the early I970s from the Bureau of Educational and Cultural Affairs of the US Department of State. The opinions expressed in this article are entirely those of the authors. 